\title{
Intratumoral administration of mRNA encoding a fusokine consisting of IFN- $\beta$ and the ectodomain of the TGF- $\beta$ receptor II potentiates antitumor immunity
}

\author{
Kevin Van der Jeught ${ }^{1}$, Patrick Tjok Joe ${ }^{1}$, Lukasz Bialkowski ${ }^{1}$, Carlo Heirman ${ }^{1}$, \\ Lidia Daszkiewicz ${ }^{1}$, Therese Liechtenstein ${ }^{2}$, David Escors ${ }^{2,3}$, Kris Thielemans ${ }^{1}$, \\ Karine Breckpot ${ }^{1}$ \\ ${ }^{1}$ Laboratory of Molecular and Cellular Therapy, Department of Biomedical Sciences, Vrije Universiteit Brussel, Brussels, \\ Belgium \\ ${ }^{2}$ Rayne Institute, University College London, London, UK \\ ${ }^{3}$ Biomedical Research Centre NavarraBiomed-Fundacion Miguel Servet, National Health Service of Navarre, Pamplona, \\ Navarre, Spain
}

Correspondence to:

Karine Breckpot, e-mail: kbreckpo@vub.ac.be

Keywords: mRNA, IFN- $\beta$, TGF- $\beta$, cancer therapy, T cell

Received: July 04, $2014 \quad$ Accepted: September 06, $2014 \quad$ Published: November 03, 2014

\section{ABSTRACT}

It is generally accepted that the success of immunotherapy depends on the presence of tumor-specific $\mathrm{CDB}^{+}$cytotoxic $\mathrm{T}$ cells and the modulation of the tumor environment. In this study, we validated mRNA encoding soluble factors as a tool to modulate the tumor microenvironment to potentiate infiltration of tumorspecific $T$ cells. Intratumoral delivery of mRNA encoding a fusion protein consisting of interferon- $\beta$ and the ectodomain of the transforming growth factor- $\beta$ receptor II, referred to as $F \beta^{2}$, showed therapeutic potential. The treatment efficacy was dependent on $\mathrm{CDB}^{+} \mathrm{T}$ cells and could be improved through blockade of PD-1/PD-L1 interactions. In vitro studies revealed that administration of $F \beta^{2}$ to tumor cells resulted in a reduced proliferation and increased expression of MHC I but also PD-L1. Importantly, $F \beta^{2}$ enhanced the antigen presenting capacity of dendritic cells, whilst reducing the suppressive activity of myeloid-derived suppressor cells. In conclusion, these data suggest that intratumoral delivery of mRNA encoding soluble proteins, such as $\mathrm{F}^{2}{ }^{2}$, can modulate the tumor microenvironment, leading to effective antitumor T cell responses, which can be further potentiated through combination therapy.

\section{INTRODUCTION}

Effective antitumor immune responses rely on the presence and functionality of $\mathrm{T}$ cells that are able to recognize and destroy tumor cells. Tumor-specific cytotoxic T lymphocytes (CTLs) are often present in the periphery and within the tumor nest of cancer patients. However, tumor-infiltrating CTLs frequently lack functional antitumor reactivity. The latter is explained by the hostile tumor environment, which is enriched with immunosuppressive cell types, such as immature myeloid cells as well as immunosuppressive factors, including transforming growth factor- $\beta$ (TGF- $\beta$ ). These inhibitory mechanisms actively quench the antitumor immune response $[1,2]$.
Over the years, the injection of various antitumor agents such as cells, proteins, nucleic acids or viral vectors, into the tumor has been thoroughly evaluated in preclinical and clinical immunotherapy studies [3]. These agents differ in their mechanism of action: some lead to (re-)activation of effector immune cells, while others counteract the immunosuppressive environment. Strategies developed to induce immune activation include the direct injection of dendritic cells (DCs), and use of DC-recruiting and/or DC-potentiating factors. Our group recently demonstrated that DCs within the tumor have the capacity to engulf mRNA [4-6]. More importantly, we showed that intratumoral delivery of mRNA encoding DC-modulating stimuli, collectively referred to as TriMix, had a therapeutic effect in tumor bearing mice [4]. In the 
context of the tumor environment, several therapies targeting immunosuppressive mediators such as myeloidderived suppressor cells (MDSCs), regulatory T (Treg) cells, and secreted factors like TGF- $\beta$ have been used. Moreover, fusokines such as the FIST protein, consisting of interleukin-2 (IL-2) and the ectodomain of the TGF- $\beta$ receptor II, have been developed to combine immune activation and tumor modulation [7, 8]. In addition, it was shown that besides activation of CTLs, modulation of the tumor environment is a prerequisite to support the effector phase of the antitumor immune response.

Given above described factors, we evaluated whether we can exploit tumor-residing DCs as 'factories' for the production of a mRNA-encoded fusokine. This novel fusokine consists of interferon- $\beta$ (IFN- $\beta$ ) and the ectodomain of the TGF- $\beta$ receptor II, and is referred to as $F \beta^{2}$. The rationale for fusing IFN- $\beta$ with a TGF- $\beta$ antagonist is based on the observation that blockade of TGF- $\beta$ within the tumor is most effective when combined with an immune activator [9]. In addition, type I IFNs, such as IFN- $\beta$ are potent activators of adaptive immune responses within the tumor environment [10]. We demonstrate that the fusokine $\mathrm{F} \beta^{2}$ modulates various cell populations, including tumor cells, DCs, MDSCs and $\mathrm{CD}^{+} \mathrm{T}$ cells, leading to the favorable therapeutic outcome after its intratumoral delivery in the form of mRNA.

\section{RESULTS}

\section{$F \beta^{2}$ mRNA is translated into a functional protein}

To address whether mRNA encoding $F \beta^{2}$, a fusion protein consisting of IFN- $\beta$ and the ectodomain of the TGF- $\beta$ receptor II (Fig. 1A), can be translated into a functional protein, we electroporated HEK293T cells with $20 \mu \mathrm{g}$ of $\mathrm{F} \beta^{2}$ or eGFP mRNA. Supernatants were collected 24 hours later. First, we determined the functionality and estimated the amount of the in vitro generated fusokine. Therefore, we quantified the expression of the type I IFN-inducible gene $M x 1$ in splenocytes cultured for 6 hours with the supernatants or with varying amounts of recombinant IFN- $\beta$. qPCR analysis demonstrated that the CT-values obtained upon treatment of splenocytes with $\mathrm{F} \beta^{2}$ supernatants was comparable to those obtained upon treatment of splenocytes with $17.1 \pm 1.7 \mathrm{ng} / \mathrm{ml}$ $(\mathrm{n}=3)$ recombinant IFN- $\beta$ (Fig. 1B). To investigate the capacity of the fusokine to neutralize TGF- $\beta$ we used the TGF- $\beta$ reporter HEK293T cell line, which expresses eGFP under the control of a TGF- $\beta$ responding promoter [11]. Indeed, higher eGFP expression was observed when the cell line was cultured with increased amounts of recombinant TGF- $\beta$ (Fig. 1C). This was greatly reduced by the presence of $F \beta^{2}$ in the supernatants (Fig. 1D). Additionally, the neutralization capacity of the fusokine was compared to a commercially available neutralizing anti-TGF- $\beta$ antibody. The capacity of $F \beta^{2}$ to neutralize TGF- $\beta$ was comparable with $20 \mathrm{ng} / \mathrm{ml}$ of the commercially available anti-TGF- $\beta$ antibody (Fig. 1D). These results are consistent with the quantity of $F \beta^{2}$ estimated based on the expression of the IFN-inducible Mxl gene (Fig. 1B). Together, these data demonstrate that the mRNA encoding the $F \beta^{2}$ fusokine is translated into a functional protein.

\section{The $\mathrm{F}^{2}$ fusokine modulates myeloid cells to improve $\mathrm{CD8}^{+} \mathrm{T}$ cell responses}

To analyze the effect of $\mathrm{F} \beta^{2}$ on DCs, we cultured them for 48 hours in supernatants of HEK293T cells that were electroporated with $20 \mu \mathrm{g}$ of $\mathrm{F} \beta^{2}$ or eGFP mRNA. DCs cultured with $20 \mathrm{ng} / \mathrm{ml}$ of recombinant IFN- $\beta$ or activated for 4 hours with $100 \mathrm{ng} / \mathrm{ml}$ LPS were used as a control. Flow cytometry analysis revealed that DCs cultured with $\mathrm{F} \beta^{2}$ displayed an enhanced expression of co-stimulatory and antigen-presenting molecules (Fig. 2A), and secreted pro-inflammatory cytokines (Fig. 2B). To further evaluate the functionality of these DCs, we performed an in vitro stimulation of OT-I cells. We demonstrated that DCs pulsed with SIINFEKL peptide and cultured in the presence of $F \beta^{2}$ lead to enhanced production of IFN- $\gamma$ by antigen-specific $\mathrm{CD}^{+}$OT-I cells (Fig. 2C-D). We next analyzed the effect of $F \beta^{2}$ on MDSCs. To that end, MDSCs that closely resemble those found within tumors were generated in vitro $[12,13]$. Of note, these MDSCs produce high levels of TGF- $\beta$ (Fig. 2E). The MDSCs were cultured for 3 days in supernatants of HEK293T cells that were electroporated with $20 \mu \mathrm{g}$ of $\mathrm{F} \beta^{2}$ or eGFP mRNA. We found that MDSCs cultured in the presence of $F \beta^{2}$ were no longer able to fully suppress the functionality of $\mathrm{CD}^{+} \mathrm{T}$ cells as shown by the ability of these T cells to produce IFN- $\gamma$ (Fig. 2F). This might be explained by the reduced cell viability and the increased expression of the surface marker sca-1 on the MDSCs cultured in F $\beta^{2}$ supernatants (Fig. 2G-I). Overall, these data suggest that $F \beta^{2}$ potentiates the antigen-presenting function of DCs, whilst decreasing the suppressive capacity of MDSCs, therefore supporting $\mathrm{CD}^{+} \mathrm{T}$ cell-mediated responses.

\section{Tumor cells treated with $\mathbf{F}^{2}$ show lower proliferation rates and increased expression levels of MHC I and PD-L1}

To investigate the effect of $\mathrm{F} \beta^{2}$ on tumor cells, we cultured tumor cells of various histological origin for 1 or 4 days with $\mathrm{F} \beta^{2}$ supernatants. Subsequently, we evaluated their phenotype and proliferation respectively. Tumor cells exposed to $\mathrm{F} \beta^{2}$ showed decreased proliferation (Fig. 3A) and enhanced expression of the antigen-presenting molecule MHC I as well as the co-inhibitory molecule 
A

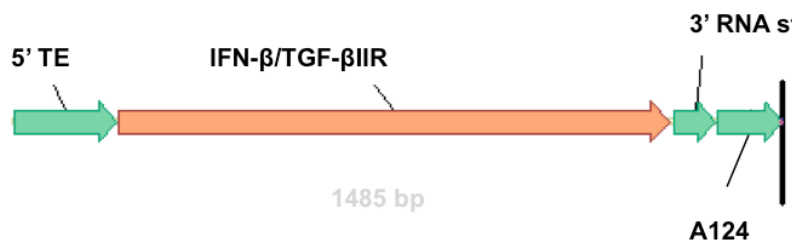

A124

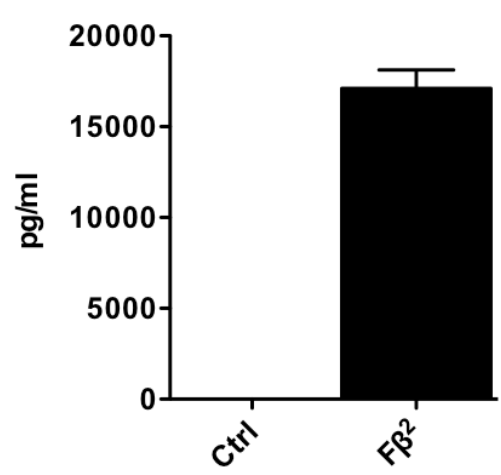

C

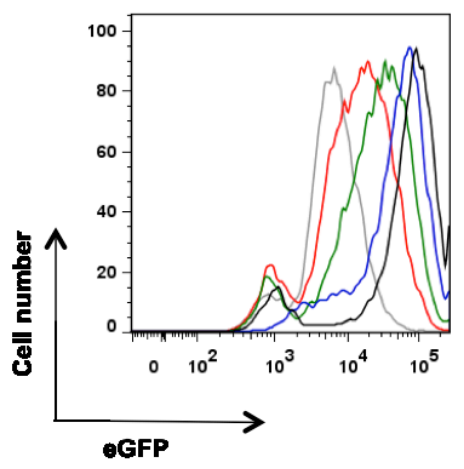

\begin{tabular}{|c|c|}
\hline rec. TGF- $\beta$ & MFI \\
\hline $0 \mathrm{pg}$ & 6018 \\
\hline $50 \mathrm{pg}$ & 13698 \\
\hline $100 \mathrm{pg}$ & 25700 \\
\hline $200 \mathrm{pg}$ & 54102 \\
\hline $400 \mathrm{pg}$ & $\mathbf{7 7 0 7 2}$ \\
\hline
\end{tabular}

D

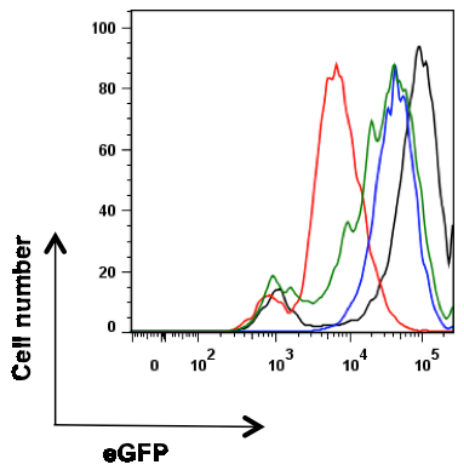

\begin{tabular}{|c|c|c|}
\hline rec. TGF- $\beta$ & Medium & MFI \\
\hline $0 \mathrm{pg}$ & Ctrl Medium & 6018 \\
\hline $200 \mathrm{pg}$ & $20 \mathrm{ng}$ Anti-TGF- $\beta$ Ab & 16708 \\
\hline $200 \mathrm{pg}$ & $\mathrm{F}^{2}$ & 14765 \\
\hline $200 \mathrm{pg}$ & Ctrl Medium & $\mathbf{5 4 1 0 2}$ \\
\hline
\end{tabular}

Figure 1: $F \beta^{2}$ mRNA is translated to a functional protein. (A) Schematic representation of the F $\beta^{2}$ mRNA construct. (B) Splenocytes were cultured for 5 hours in $\mathrm{F} \beta^{2}$, control (Ctrl) supernatants or exposed to increasing amounts of recombinant IFN- $\beta$. qPCR was performed to determine $M x 1$ expression. The graph depicts the amount of fusokine ( $\mathrm{pg} / \mathrm{ml})$. The quantity was determined based on the expression of $M x 1$ upon treatment with recombinant IFN- $\beta$ and normalized to $2^{-\Delta c t}$ for Ppia $(\mathrm{n}=3)$. (C) The TGF- $\beta$ reporter HEK293T cell line was cultured for 24 hours in 0 to $400 \mathrm{pg} / \mathrm{ml}$ of recombinant TGF- $\beta$ (rec. TGF- $\beta$ ). The histogram overlay depicts the eGFP expression. Representative plots are shown $(n=4)(D)$ The TGF- $\beta$ reporter HEK293T cell line was cultured for 24 hours in F $\beta^{2}$, Ctrl supernatants or exposed to $20 \mathrm{ng}$ of a commercial available anti-TGF- $\beta$ antibody, and supplemented with $200 \mathrm{pg}$ of recombinant TGF- $\beta$. The histogram overlay depicts the eGFP expression. Representative plots are shown $(n=3)$.

PD-L1 (Fig. 3B-C). Next we analyzed whether exposure of E.G7-OVA cells to $\mathrm{F} \beta^{2}$ facilitated their recognition by activated $\mathrm{CD}^{+}$OT-I cells (Fig. 3D) despite PD-L1 up-regulation. These $\mathrm{T}$ cells showed an increased cytolytic activity (Fig. 3E-F), indicating that the expression of PD-L1 on tumor cells did not completely abrogate their recognition by $\mathrm{T}$ cells.

\section{Simultaneous exposure of tumor cells and $\mathrm{CDB}^{+}$ $T$ cells to $F \beta^{2}$ significantly enhances the killing capacities of antigen-specific $T$ cells}

To investigate the direct effect of $\mathrm{F}^{2}$ on $\mathrm{CD} 8^{+} \mathrm{T}$ cells, we cultured CD8 $8^{+}$OT-I spleen cells for 3 days in supernatants of HEK293T cells that were electroporated 
A

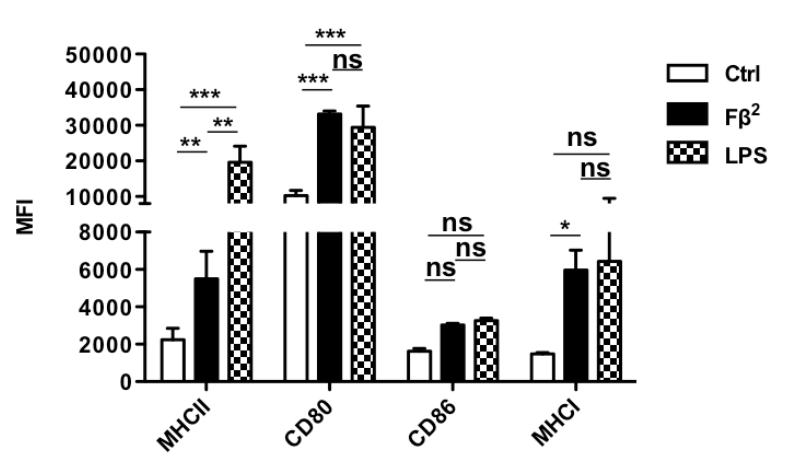

C

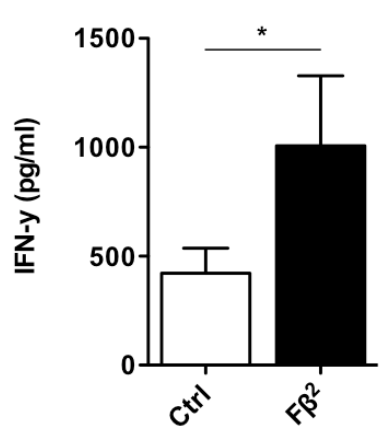

F

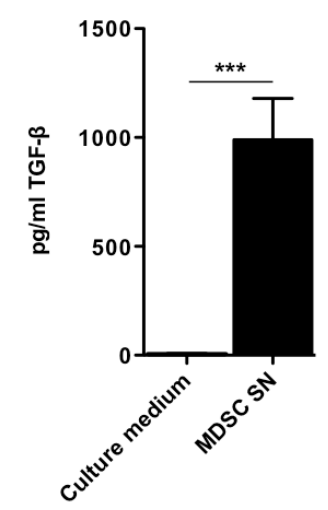

D

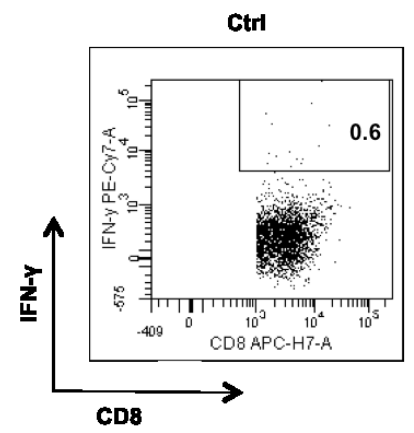

G

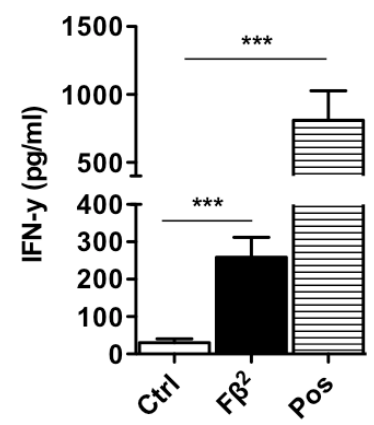

B

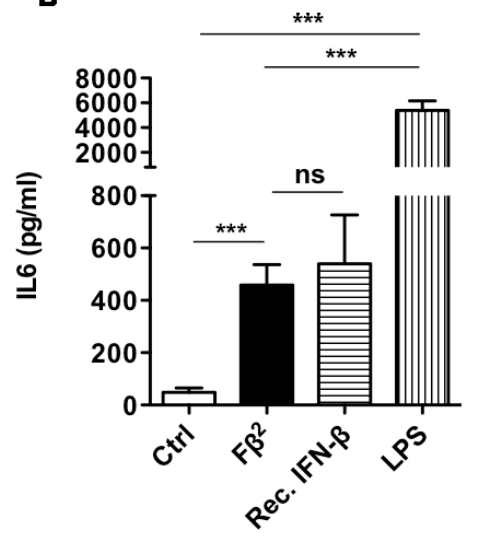

H

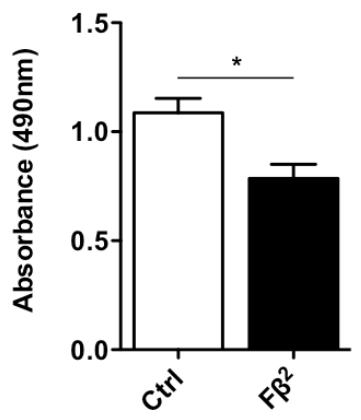

E
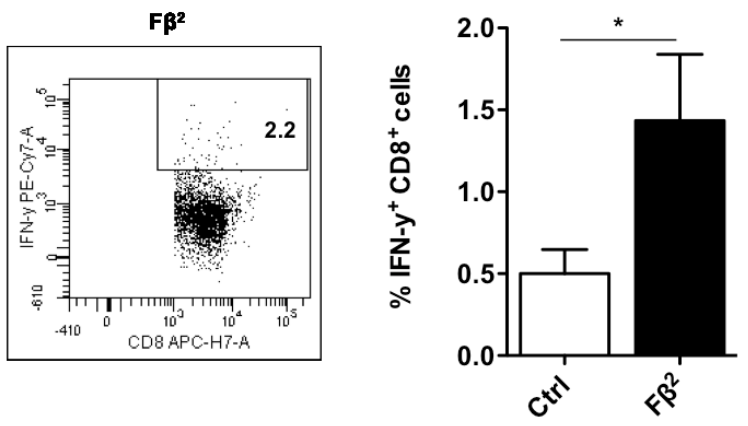

I

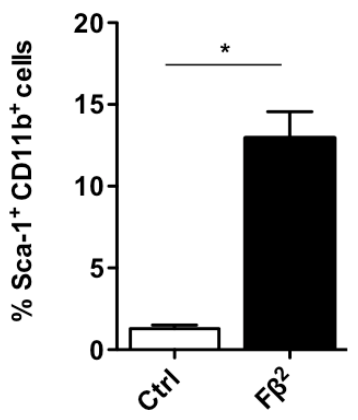

Figure 2: The $\mathbf{F} \boldsymbol{\beta}^{2}$ fusokine modulates myeloid cells to improve $\mathbf{C D 8}^{+} \mathbf{T}$ cell responses. (A-E) DCs were cultured for 48 hours in $\mathrm{F}^{2}$ or Control (Ctrl) supernatants. (A) Expression of MHC II, CD80, CD86 and MHC I was evaluated by flow cytometry. The column graph depicts the median fluorescence intensity (MFI) $(n=6)$. (B) Supernatants were analyzed for the presence of IL-6 and TNF- $\alpha(n=3-12)$. (C-E) DCs were pulsed with the peptide SIINFEKL and co-cultured for 6 days with CD8 $8^{+}$OT-I cells at a 1:10 ratio. (C) The production of IFN- $\gamma$ by OT-I cells was determined by ELISA $(n=9)$. (D) The production of IFN- $\gamma$ by OT-I cells was confirmed via flow cytometry. Representative plots are show. (E) The column graph depicts the results of the experiments ( $\mathrm{n}=6$ ). (F) The TGF- $\beta$ reporter HEK293T cell line was cultured for 24 hours in the conditioned medium used to generate MDSCs or in supernatants of in vitro generated day 5 MDSCs (n=3). (G-I) MDSCs were cultured for 3 days in F $\beta^{2}$ or Ctrl supernatants. (G) These MDSCs were co-cultured for 3 days with $\mathrm{CD}^{+}$splenocytes that were activated with anti-CD3/anti-CD28 beads. Activated CD8 ${ }^{+}$splenocytes cultured in the absence of MDSCs served as a positive control (Pos). Supernatants were screened for the presence of IFN- $\gamma(n=4)$. (H) MDSC viability was assessed using a colorimetric assay. The colorimetric assay reflects the amount of viable cells in the plate, and is measured as absorbance. The graph depicts the absorbance $(n=3)$. (I) Flow cytometry was performed to assess the percentage of CD11b and sca- $1^{+}$cells $(n=3)$. 
A

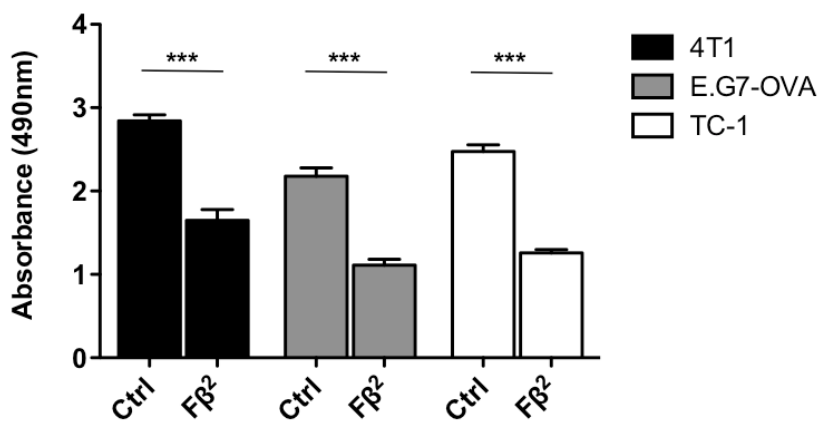

C

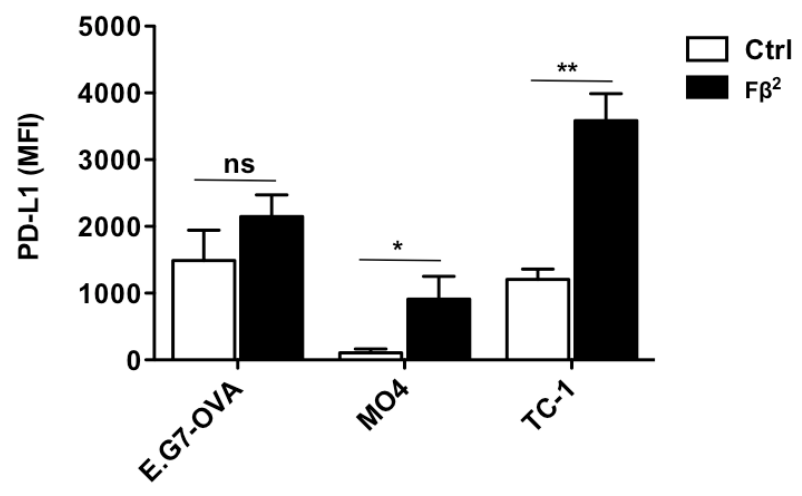

E

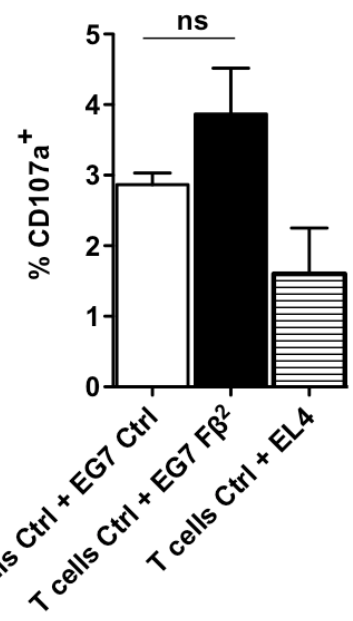

$\mathbf{F}$

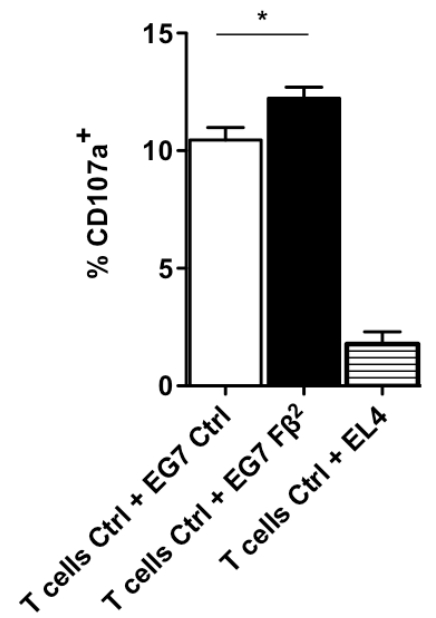

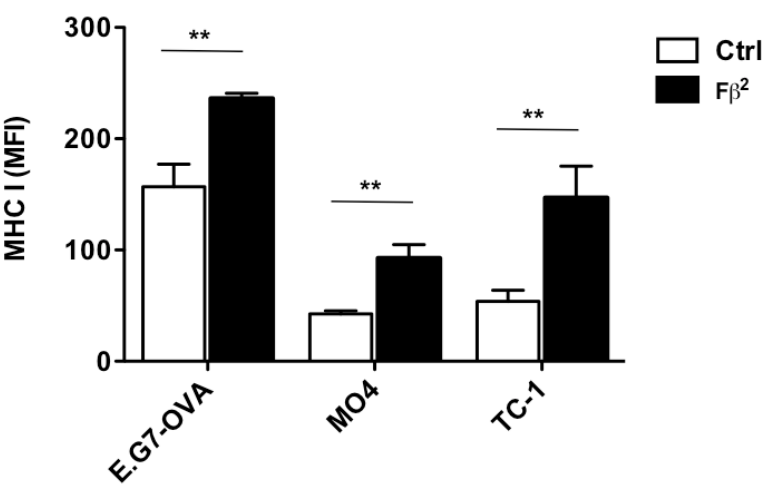

D

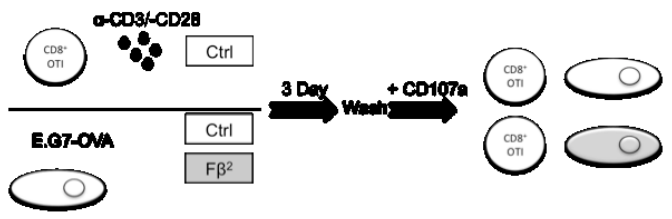

Figure 3: Tumors treated with $\mathrm{F}^{2}$ show lower proliferative rates and express increased levels of MHC I and PD-L1. (A) 4T1, E.G7-OVA and TC-1 tumor cells were cultured for 4 days in F $\beta^{2}$ or Ctrl supernatants. Cell proliferation was assessed using a colorimetric assay ( $\mathrm{n}=3$ ). (B-C) E.G7-OVA, MO4 and TC-1 cells were cultured for 24 hours in F $\beta^{2}$ or Ctrl supernatants, after which expression of (B) MHC I and (C) PD-L1 was evaluated by flow cytometry. The column graphs depict the MFI (n=3). (D-F) E.G7-OVA tumor cells were cultured for 3 days in $\mathrm{F}^{2}$ or Ctrl supernatants, after which they were co-cultured with CD8 ${ }^{+}$OT-I spleen cells in the presence of anti-CD107 antibodies for 4 hours at a tumor:T cell ratio of 1:10 (E) and 1:1 (F). Four hours later cells were additionally stained for CD3 and CD8. The graphs depict the amount of CD107a and CD8 $8^{+}$cells $(n=3)$.

with $20 \mu \mathrm{g}$ of $\mathrm{F} \beta^{2}$ or eGFP mRNA. Simultaneously, E.G7-OVA tumor cells were cultured in $F \beta^{2}$ containing supernatants. Subsequently, co-cultures were set up according to the scheme shown in figure $4 \mathrm{~A}$, and the degranulation ability of the $\mathrm{CD} 8^{+} \mathrm{OT}-\mathrm{I}$ cells was evaluated (Fig. 4B-D). We demonstrated that $\mathrm{CD}^{+}$OT-I cells pretreated with $\mathrm{F} \beta^{2}$ recognized tumor cells more efficiently and that this recognition was enhanced when tumor 
cells were pretreated with $\mathrm{F} \beta^{2}$ (Fig. 4C-D). In summary, we showed that the $\mathrm{F} \beta^{2}$ fusokine potentiates the killing capacity of $\mathrm{CD}^{+} \mathrm{T}$ cells.

\section{Intratumoral delivery of F $\beta^{2}$ mRNA delays tumor growth}

To analyze the therapeutic potential of mRNA encoding the $\mathrm{F} \beta^{2}$ fusokine, we first treated mice bearing E.G7-OVA tumors with a single intratumoral injection of $10 \mu \mathrm{g}$ of $\mathrm{F} \beta^{2}$ mRNA. Mice treated with a single injection of $10 \mu \mathrm{g}$ tNGFR mRNA served as a control. Tumor growth was delayed over a period of three days (Fig. 5A), after which the effect was no longer detected (data not shown). Therefore, we subsequently treated tumor-bearing mice with three intratumoral injections of $10 \mu \mathrm{g} \mathrm{F} \beta^{2}$ or tNGFR mRNA at a three-day interval, which resulted in a prolonged survival of the mice (Fig. 5B). To further improve this therapeutic outcome, we further increased the dose of mRNA to $50 \mu \mathrm{g}$ and delivered the

A

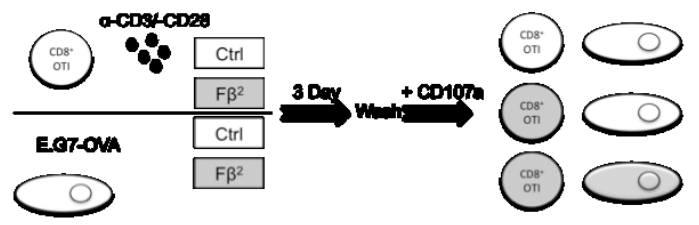

C

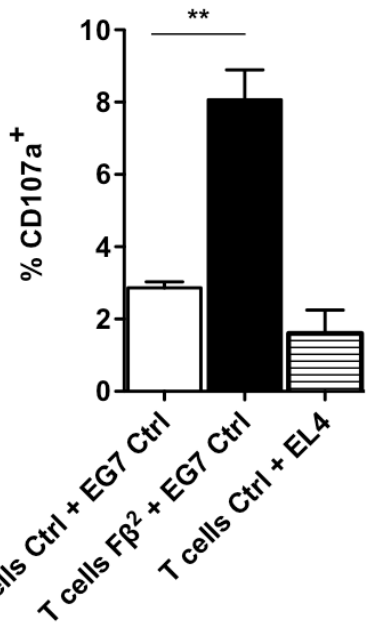

mRNA continuously at a three-day interval (Fig. 5C). This regimen was compared to the delivery of $10 \mu \mathrm{g}$ of mRNA. Mice treated with repeated injections of the vehicle (0.8 Lactated Ringer's solution) were used as a control. Notably, the treatment with $50 \mu \mathrm{g}$ of tNGFR mRNA prolonged mice survival when compared to the treatment with $10 \mu \mathrm{g}$ of tNGFR mRNA. In addition, we observed that in the groups treated with $10 \mu \mathrm{g}$ of mRNA, the non-stop treatment regimen did not improve the survival as compared to the three-day regimen (Fig. 5B-C). Importantly, four out of eight mice treated with $50 \mu \mathrm{g}$ of $\mathrm{F} \beta^{2}$ mRNA demonstrated a long-term survival when compared to mice treated with $10 \mu \mathrm{g} \mathrm{F} \beta^{2}$ mRNA or $50 \mu \mathrm{g}$ of tNGFR mRNA (Fig. 5C). Based on these data, an optimal treatment regimen consisting of three immunizations at a three-day interval with $50 \mu \mathrm{g}$ of mRNA was defined and then applied to the treatment of mice bearing TC-1 tumors (Fig. 6A). Consistent with the E.G7-OVA model, we observed an immediate and a prolonged delay in TC-1 tumor growth (Fig. 6B-C). Consequently, these mice
$\mathbf{E}$
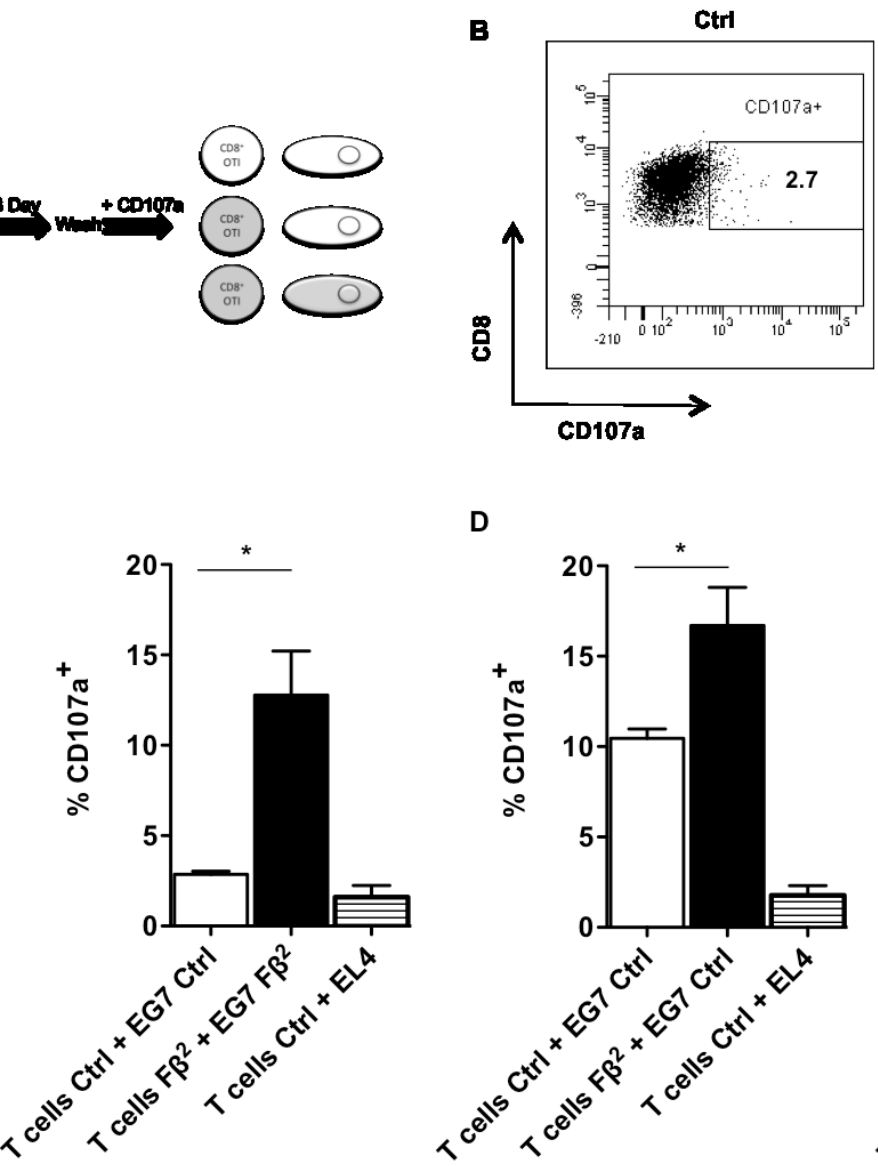

D

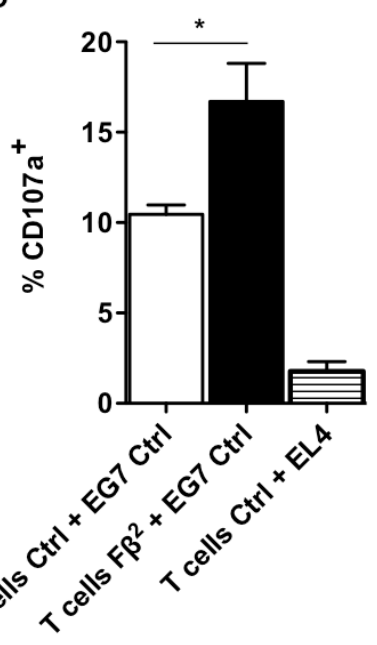

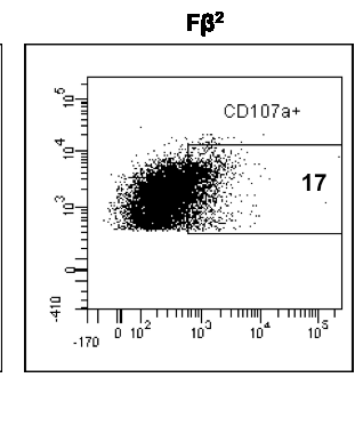

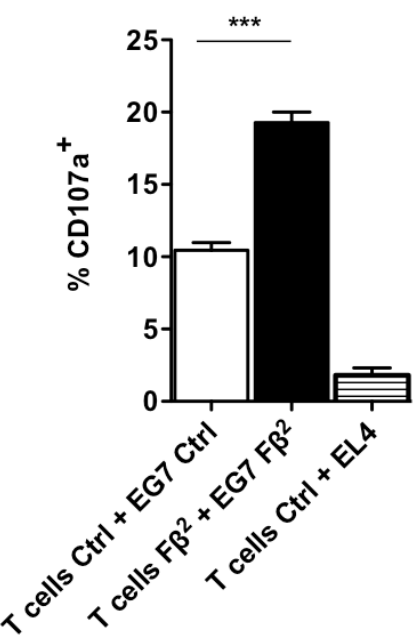

Figure 4: Simultaneous exposure of tumor cells and CD8 $\mathrm{T}$ cells to $\mathrm{F} \boldsymbol{\beta}^{2}$ significantly enhances the killing capacities of antigen-specific $\mathbf{T}$ cells. (A) CD8 ${ }^{+}$OT-I spleen cells were cultured for 3 days in F $\beta^{2}$ or Ctrl supernatants. Simultaneously, E.G7-OVA tumor cells were cultured for 3 days in these supernatants. Subsequently, both cell populations were washed and mixed together as depicted. These were co-cultured in the presence of anti-CD107 antibodies for 4 hours at a tumor:T cell ratio of (C) 10:1 or (D) 1:1, after which the T cells were labeled with anti-CD3 and anti-CD8 antibodies. (B) The flow cytometry graphs are representative for the experiments. (C-D) The graphs depict the percentage of CD107a within $\mathrm{CD}^{+} \mathrm{T}$ cells in the co-cultures ( $\mathrm{n}=3$ and $\mathrm{n}=4$, respectively). 

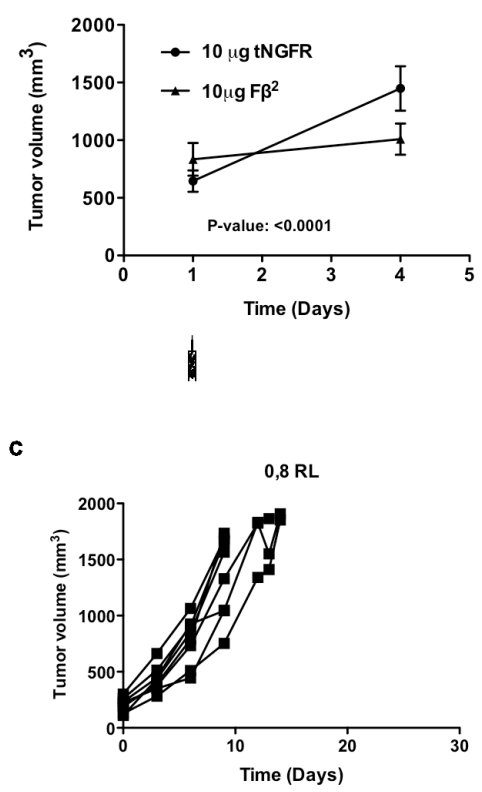

hith
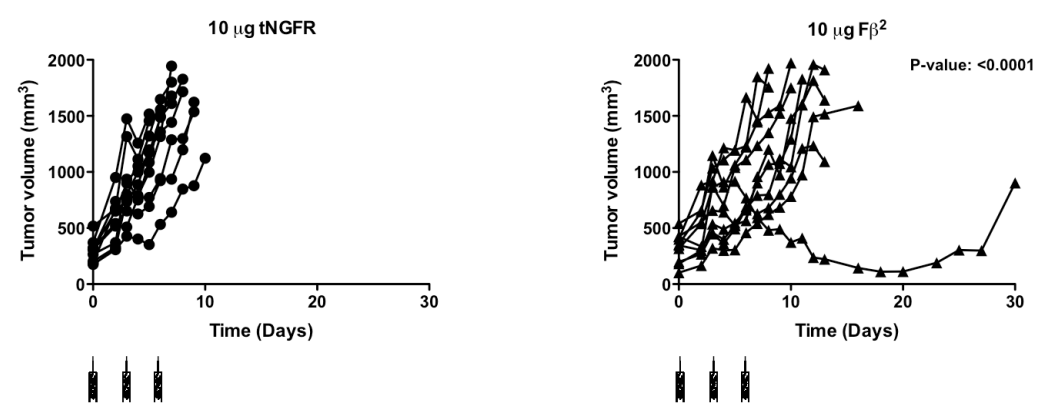

$\|$

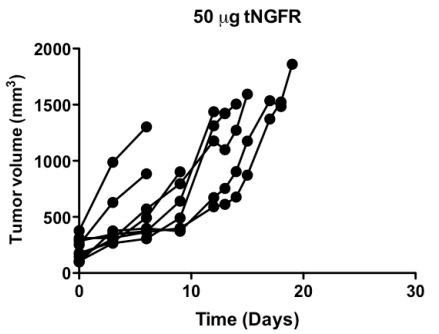

ihilith

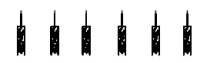

$10 \mu \mathrm{gF} \beta^{2}$

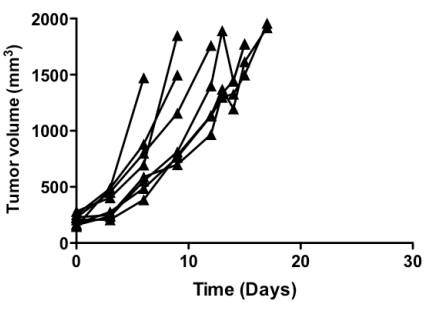

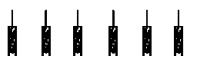

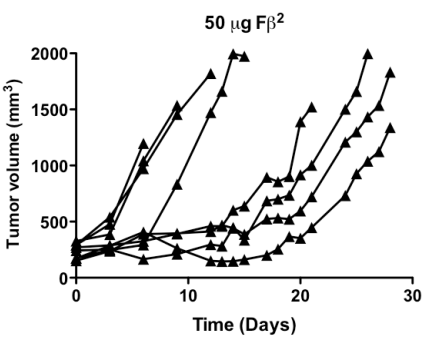

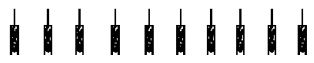

Figure 5: Intratumoral delivery of $F^{2}{ }^{2}$ mRNA to E.G7-OVA bearing mice delays tumor growth. (A-C) E.G7-OVA cells $\left(5 \times 10^{6}\right)$ were transplanted subcutaneously in C57BL/6 mice. (A) Mice were treated with a single intratumoral injection of $10 \mu \mathrm{g}$ mRNA encoding tNGFR (circle) or F $\beta^{2}$ (triangle). The graph shows the average tumor size at the day of treatment and 3 days later for a total of 11 mice and summarizes the results of 4 independent experiments. (B) Mice (10 per group) were treated with 3 intratumoral injections of $10 \mu \mathrm{g}$ of tNGFR (circle) or F $\beta^{2}$ (triangle) mRNA at three-day intervals. The graph depicts the size of the tumor of individual mice. (C) Mice (8 per group) were treated with consecutive intratumoral injections of $0.8 \mathrm{RL}$ (square), 10 or $50 \mu \mathrm{g}$ of tNGFR (circle) or F $\beta^{2}$ (triangle) mRNA at three-day interval. The graph depicts the size of the tumor of individual mice.

showed an increased survival (Fig. 6D). To investigate the role of $\mathrm{CD}^{+} \mathrm{T}$ cells in this therapeutic outcome, we depleted this cell population prior and during the treatment (Fig. 6E). The results showed that $\mathrm{CD}^{+} \mathrm{T}$ cells are the predominant cell type involved in the observed antitumor activity, since their depletion abrogated the therapeutic effect of the $F \beta^{2}$ fusokine (Fig. 6F-G).

\section{Blockade of the PD-1/PD-L1 interaction combined with $\mathbf{F} \beta^{2}$ mRNA treatment improves therapeutic responses}

Although intratumoral injection of $F \beta^{2}$ mRNA induces therapeutic responses, we demonstrated both in vitro (Fig. $3 \mathrm{C}$ ) and in vivo (data not shown) that $\mathrm{F} \beta^{2}$ mRNA induces PD-L1 up-regulation. We therefore wondered whether additional targeting of the PD-1/PD-L1 pathway could improve therapeutic responses. To test this, we combined intratumoral delivery of $F \beta^{2}$ mRNA with three intraperitoneal injections of anti-PD1 monoclonal antibodies (Fig. 7A-B). This resulted in an inhibition of TC-1 tumor growth (Fig. 7B). We next increased the amount of tumor cells injected, hereby mimicking a faster growing tumor setting. In this case, no effect was observed for the single treatment with $\mathrm{F} \beta^{2}$ mRNA or anti-PD1 alone (Fig. 7C). However, the combination of $\mathrm{F} \beta^{2} \mathrm{mRNA}$ and anti-PD1 resulted in a delayed tumor growth and thus in an increased survival. 


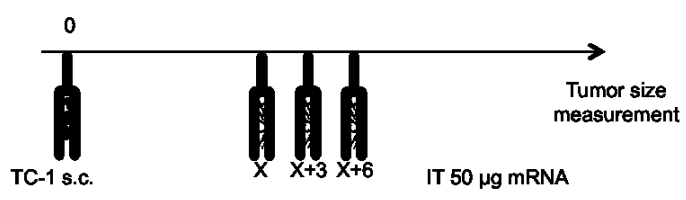

B
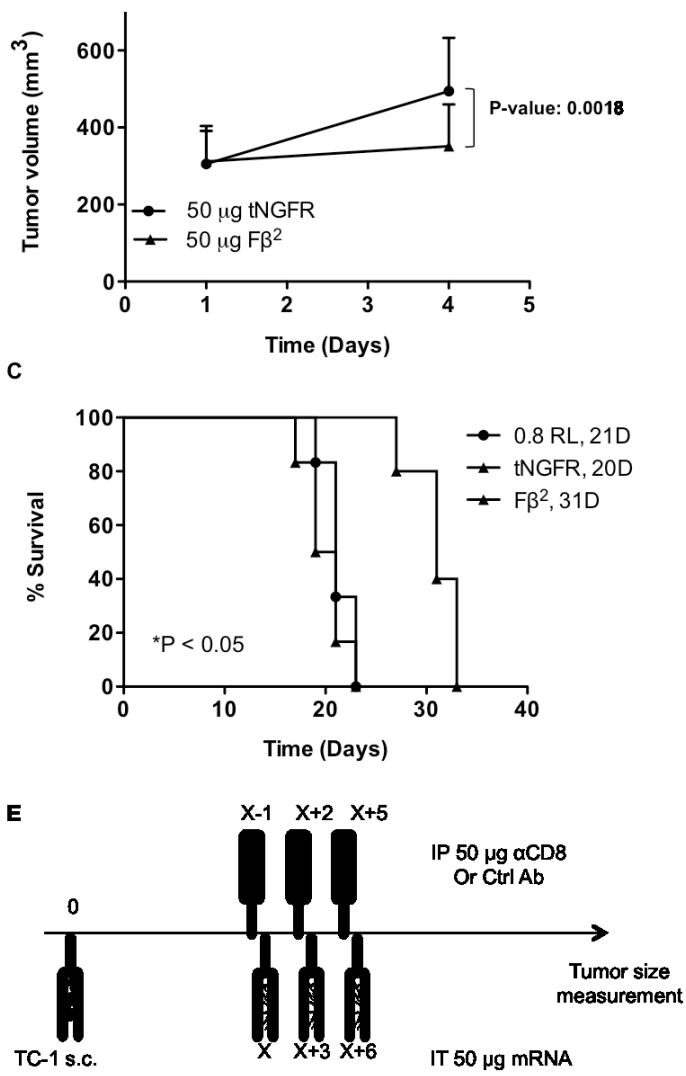

$\mathbf{F}$

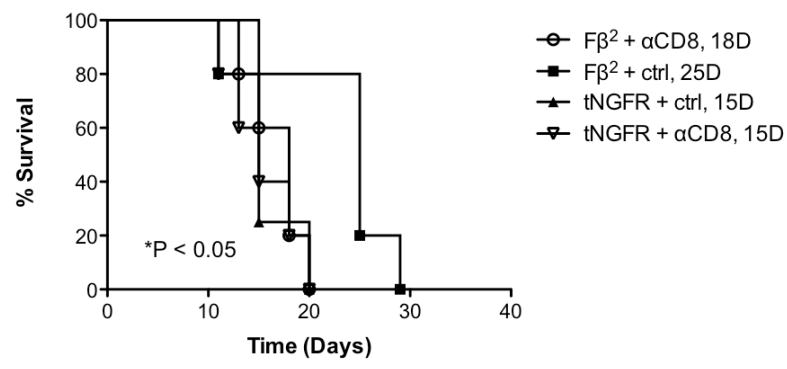

D
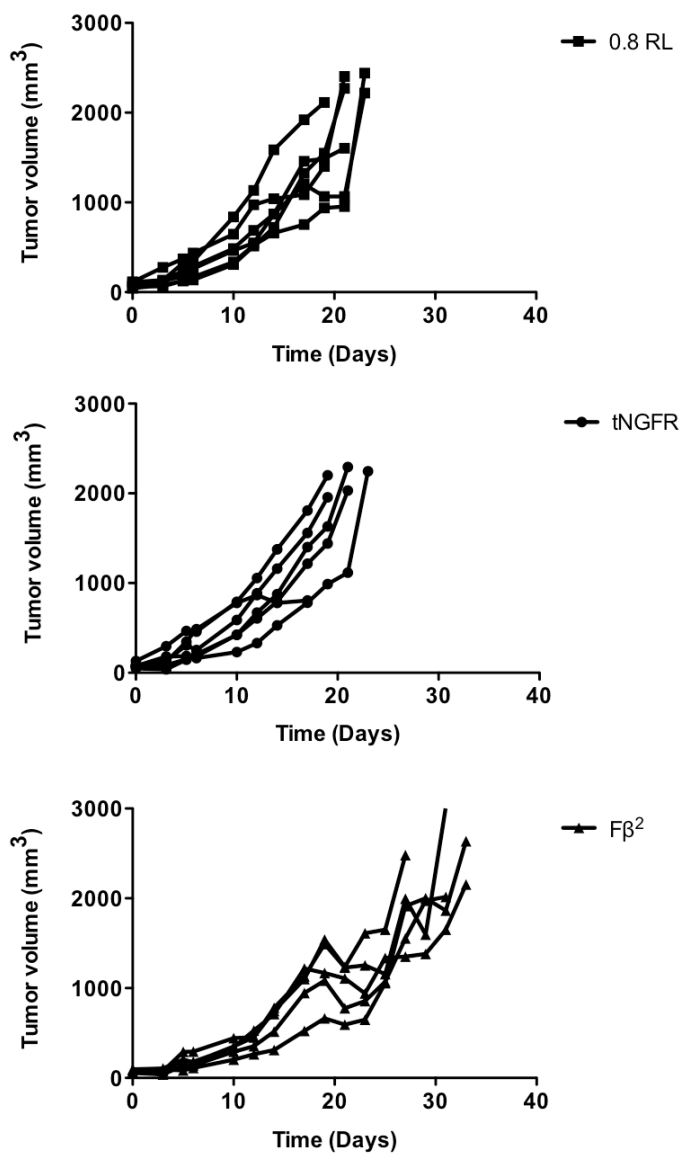

G

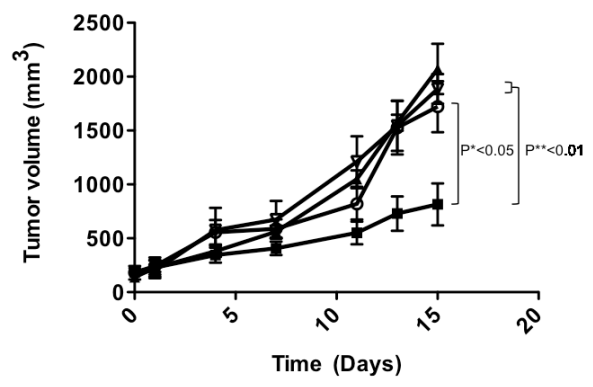

Figure 6: Intratumoral delivery of $\mathbf{F}^{2}$ mRNA to TC-1 bearing mice delays tumor growth. (A-G) TC-1 cells were transplanted subcutaneously in C57BL/6 mice. Once the tumors reached an average size of $100 \mathrm{~mm}^{3}$ the mice were treated according to the scheme shown in A. Tumor growth was monitored. (B) The graph shows the average tumor size at the day of treatment and 3 days later $(\mathrm{n}=11)$. (C-D) Mice (5-6 per group) were treated with 3 intratumoral injections of $0.8 \mathrm{RL}$ (square), $50 \mu \mathrm{g}$ of tNGFR (circle) or F $\beta^{2}$ (triangle) mRNA at three-day intervals. (C) The graph depicts the median survival. (D) The graph depicts the growth of tumors in individual mice. (E) Treatment regimen with $\mathrm{CD}^{+} \mathrm{T}$ cell depletion. (F) The graph depicts the survival of the mice treated as in E. (G) The graph depicts the mean of the tumor sizes of the respective groups (5 mice per group). 
A

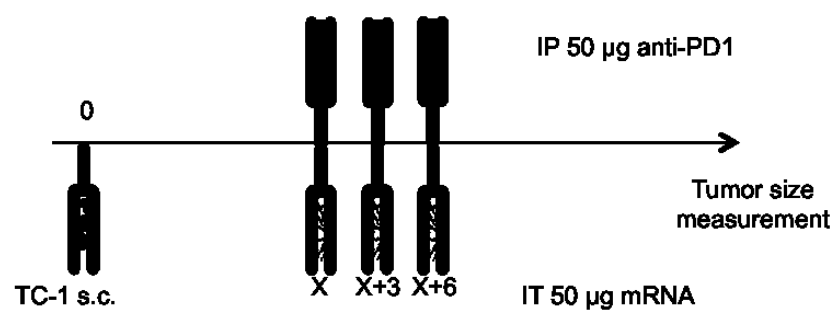

B

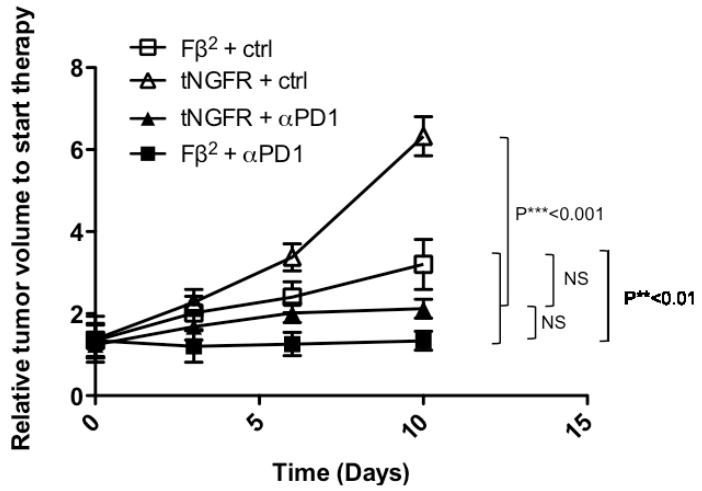

C

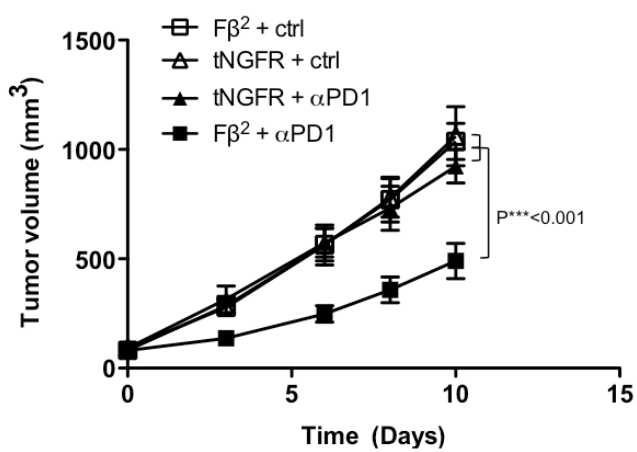

Figure 7: Blockade of PD-1/PD-L1 interactions combined with F $^{2} \mathbf{m R N A}$ treatment improves therapeutic responses. TC-1 cells were transplanted subcutaneously in C57BL/6 mice (5 per group). (A-C) Once the tumors reached a size of $100-500 \mathrm{~mm}^{3}$ mice were treated according to the scheme shown in A. Subsequently, tumor growth was monitored. (B) The graph depicts the mean of the tumor sizes of the respective groups when applying a less aggressive model using $2 \times 10^{4} \mathrm{TC}-1$ cells. (C) The graph depicts the mean of the tumor sizes of the respective groups when applying a more aggressive model using $2 \times 10^{5} \mathrm{TC}-1$ cells.

\section{DISCUSSION}

In this study, we demonstrated the feasibility of intratumoral delivery of mRNA encoding immunomodulating proteins to fine-tune the tumor environment and confer antitumor immunity. More specifically, we evaluated the ability of a fusokine called $\mathrm{F} \beta^{2}$, composed of IFN- $\beta$ and the ectodomain of the TGF- $\beta$ receptor II.

Over the years, much effort has been put into priming and generating highly potent tumor-specific CTLs by means of cancer vaccination [14]. Although this strategy leads to the priming of tumor-specific CTLs [15], these $\mathrm{T}$ cells display reduced functionality due to exposure to the inhibitory mechanisms at the tumor site, which might explain poor results in the control of established tumors upon cancer vaccination. Several approaches are currently under development to tackle this problem. The success of anti-CTLA-4, anti-PD-L1 and anti-PD-1 antibodies in the treatment of various cancer types undoubtedly supports the idea of targeting inhibitory mechanisms that drive CTL dysfunctionality [16-18].
Here we evaluated the use of mRNA encoding the fusokine $F \beta^{2}$ as a tool to deliver proteins with immunomodulating capacity. This work builds on the previous finding that mRNA can be delivered to the tumor and is engulfed by DCs $[4,5]$. Based on these results we hypothesized that DCs could be exploited as 'factories' for the production of immunomodulating proteins. Moreover we prove the feasibility of using mRNA encoding a novel fusokine $F \beta^{2}$, consisting of IFN- $\beta$ and the ectodomain of the TGF- $\beta$ receptor II. The combination of IFN- $\beta$ and a TGF- $\beta$ signaling antagonist was recently shown to have promising antitumor effects [19].

Type I IFNs have been described as stimulants of DC differentiation and maturation [20,21]. In addition, it was recently demonstrated by Fuertes et al [22] that IFN- $\beta$ plays an essential role in priming of $\mathrm{T}$ cells by attracting $\mathrm{CD} 8 \alpha^{+} \mathrm{DCs}$ to the tumor environment. This subset of DCs is important for the cross-presentation of tumor antigens to $\mathrm{CD} 8^{+} \mathrm{T}$ cells and lack of this population results in defective $\mathrm{CD}^{+} \mathrm{T}$ cell immune responses. Importantly, Van Lint et al proved that $\mathrm{CD} 8 \alpha^{+} \mathrm{DCs}$ are the main cell population involved in the uptake of mRNA 
in the tumor [5]. We demonstrated that $\mathrm{F} \beta^{2}$ induces DC activation. Surprisingly, F $\beta^{2}$ matured DCs did not secrete enhanced IL-12 levels (data not shown). It has been shown that IL-6 secretion by DCs stimulated with type I IFNs plays a major role in the protection of $\mathrm{T}$ cell effector functions from the suppressive capacity of Treg cells [23]. In accordance with their maturation status, these DCs were able to stimulate antigen-specific $\mathrm{CD}^{+} \mathrm{T}$ cells.

Tumors have the capacity to take advantage of myeloid cell plasticity in order to skew them towards an immunosuppressive phenotype [24], which is confirmed by the presence of MDSCs within tumors. To study the effects of $\mathrm{F} \beta^{2}$ on MDSCs, we generated these cells in vitro as it was recently shown that large numbers of MDSCs that closely resemble MDSCs found within the tumor, could be induced $[12,13]$. This resemblance was phenotypically based on inter alia the high expression of PD-L1, Arg-1 and CD86 and the lower expression of CD62L [13]. This is of a particular importance given difficulties in obtaining high numbers of pure MDSCs from tumors. Moreover it was also established that splenic MDSCs from tumor-bearing mice are phenotypically and functionally distinct from tumor MDSCs [24]. In accordance with previous reports, we demonstrated that in vitro generated MDSCs secrete high levels of TGF- $\beta$, a characteristic feature of in vivo tumor-infiltrating MDSCs $[12,13]$. This local accumulation of TGF- $\beta$ was shown to be accompanied with different immunosuppressive cell types, making TGF- $\beta$ a core soluble factor in skewing the immunosuppressive balance [25-27]. In addition, type I IFNs have direct effects on the phenotype and function of myeloid cells. TGF- $\beta$ antagonists and type I IFNs hamper MDSC-mediated suppressive functions $[28,29]$. This effect could be linked to the induction of apoptosis as shown by Ellermeier et al [29]. MDSCs exposed to both TGF- $\beta$ blockade and type I IFNs display an increased expression of CD11c, CD80 and a decrease in the granulocytic fraction $[28,29]$. Interestingly, sca-1 up-regulation on MDSCs inversely correlates with their suppressive capacity [29], and our fusokine increases the expression of this marker on treated MDSCs.

Consistent with a previous study showing that MHC I on tumor cells is up-regulated upon treatment with IFN- $\beta$, we demonstrated that $F \beta^{2}$ enhanced MHC I expression [30]. Loss of MHC I expression on cancer cells allows them to escape immunosurveillance, by making them invisible to $\mathrm{CD}^{+} \mathrm{T}$ cells [31]. By enhancing MHC I expression, $\mathrm{F} \beta^{2}$ showed to increase tumor cell recognition by $\mathrm{CD}^{+} \mathrm{T}$ cells. This was confirmed in a coculture of $\mathrm{CD}^{+}$OT-I cells with tumor cells, exposed or not to the $\mathrm{F} \beta^{2}$ fusokine. However, the increase in tumor cell recognition was moderate, which might be explained by the enhanced PD-L1 expression on tumor cells treated with $\mathrm{F} \beta^{2}[32,33]$. Up-regulation of $\mathrm{PD}-\mathrm{L} 1$ is a major obstacle in IFN- $\beta$ based cancer immunotherapy as it can lead to $\mathrm{T}$ cell anergy and apoptosis through interaction with PD-1 [34, 35], but can also down-modulate T cell effector activities [36]. Targeting of this PD-1/PD-L1 interaction in type I IFN based therapy was shown to improve the therapeutic outcome [37, 38]. Importantly, we demonstrated that recognition of tumor cells pretreated with $F \beta^{2}$ was augmented when T cells were exposed to $\mathrm{F} \beta^{2}$. Taken together, our in vitro findings point out that delivery of $\mathrm{F} \beta^{2}$ to the tumor environment might lead to a 'CTL-supporting' rather than a 'CTL-suppressive' environment. This was further confirmed by our in vivo data. We showed that intratumoral delivery of $\mathrm{F} \beta^{2} \mathrm{mRNA}$ results in a delayed tumor outgrowth. The benefit of the $\mathrm{F} \beta^{2}$ mRNA therapy was dependent on $\mathrm{CD}^{+} \mathrm{T}$ cells, as the antitumor effect of the therapy was abrogated when mice were depleted of this cell population. We showed that the prolonged delay in growth was dependent on the repeated delivery of $F \beta^{2}$ mRNA. The latter is consistent with the findings of Narumi et al [23], who indicated that low levels of type I IFNs were needed for at least 10 days to obtain successful antitumor immunity. Finally, we demonstrated in vivo that additional targeting of the PD-1/ PD-L1 interaction improved the $\mathrm{F} \beta^{2}$ therapy, confirming the detrimental impact of PD-1 engagement on $\mathrm{T}$ cells in the tumor environment.

In conclusion, we established the feasibility of using mRNA encoding immunomodulating proteins to modulate the tumor environment. We provide evidence that $\mathrm{F} \beta^{2}$ works via a multistep process acting on $\mathrm{DCs}$, MDSCs, $\mathrm{CD}^{+} \mathrm{T}$ cells as well as tumor cells. Its effect can be further enhanced through additional blockade of PD-1/ PD-L1 interactions. This study supports therefore the paradigm that combining immunotherapeutic antitumor strategies might tackle the immunosuppressive tumor environment and lead to an improved outcome [39].

\section{MATERIALS AND METHODS}

\section{Mice}

6-12 week old female C57BL/6 mice (Charles River, Wilmington, USA) were housed and handled according to the regulations of the Animal Care Committee of the Vrije Universiteit Brussel (VUB). OT-I mice that carry a transgenic $\mathrm{CD} 8^{+} \mathrm{T}$ cell receptor (TCR) specific for the MHC class I-restricted ovalbumin $\left(\mathrm{OVA}_{257-264}\right)$ peptide SIINFEKL were provided by B. Lambrecht (University of Ghent, Ghent, Belgium).

\section{Cell lines and Reagents}

The human embryonal kidney (HEK) 293T, the breast cancer 4T1, the melanoma B16-F0 and the T-cell lymphoma E.G7-OVA cell lines were obtained from the American Type Culture Collection (Rockville, Maryland, USA). The TGF- $\beta$ reporter HEK293T cell line was previously described [40]. The mouse melanoma cell 
line MO4 and the lung carcinoma cell line TC-1 were kindly provided by K. Rock (University of Massachusetts Medical Center, Massachussetts, USA) and T.C. Wu (Johns Hopkins Medical Institution, Baltimore, Maryland, USA). The recombinant IFN- $\beta$ was purchased from Biolegend. The neutralizing anti-TGF- $\beta$ antibody was purchased from eBioscience (clone 1D11.16.8). The antiCD8 (2.43), anti-PD1 (J43) and isotype control (Hamster IgG) monoclonal antibodies were purchased form BioXCell (New Hampshire, USA).

\section{mRNA production}

mRNA encoding $F \beta^{2}$ (1485 base pairs) is comprised of a 5' terminal cap, the genetic sequence encoding a fusion protein consisting of mouse IFN- $\beta$ and the ectodomain of TGF- $\beta$ receptor II, a 3' RNA stabilizing

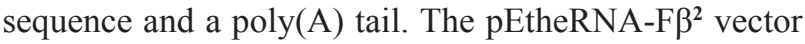
used to produce the mRNA encoding the $F \beta^{2}$ fusokine (produced by eTheRNA, Kortenberg, Belgium) was linearized at the 3 ' end of the poly(A) tail using the restriction enzyme Bsp M1. The mRNA was produced by in vitro transcription as previously described [41]. The production of mRNA encoding the reporter eGFP or truncated nerve growth factor receptor (tNGFR) was previously described [41].

\section{Electroporation of HEK293T cells with mRNA}

Electroporation of HEK293T cells with mRNA was performed according to the protocol described for mRNA electroporation of DCs [42].

\section{Intratumoral administration of mRNA}

C57BL/6 mice were inoculated subcutaneously with $5 \times 10^{5}$ E.G7-OVA cells, $2 \times 10^{4}$ or $2 \times 10^{5}$ TC- 1 cells. Tumors with a volume of $100-500 \mathrm{~mm}^{3}$ were injected intratumorally with $50 \mu$ of the indicated amount of mRNA dissolved in 0.8 Lactated Ringer's solution (0.8RL).

\section{RNA isolation, cDNA synthesis and real-time PCR}

Total RNA was isolated using the SV Total RNA Isolation System (Promega, Madison, USA). The extracted RNA was reverse transcribed into cDNA with the RevertAid ${ }^{\text {TM }}$ H Minus First Strand cDNA Synthesis Kit (Fermentas Inc., Maryland, USA) using the random hexamer primers. Samples were subjected to real-time PCR analysis on an ABI PRISM 7700 Sequence Detection System (Applied Biosystems, Life Technologies, Ghent, Belgium). Primers for amplification of $M x 1$ were as follows: 5'-CGAGAAGTCCGGAAGCTTGT-3' and 5'-CATGtACTGAGAAGTTTCATGCA-3'; Probe
FAM-CAATTGCCGTCACCGTTCGTTTTCA -TAMRA (Eurogentec, Seraing, Belgium). Primers for the amplification of peptidylprolyl isomerase A (Ppia) were as follows: 5'-TTCACCTTCCCAAAGACCAC-3' and 5'CAAACACAAACGGTTCCCAG-3'; Probe FAMTGCTTGCCA/ZEN/TCCAGCCATTCAG-3IABkFQ (Integrated DNA Technologies, Leuven, Belgium).

\section{In vitro generation of dendritic cells and myeloid-derived suppressor cells}

Bone marrow-derived DCs were generated and activated with $20 \mathrm{ng} / \mathrm{ml}$ recombinant IFN- $\beta$ or $100 \mathrm{ng} / \mathrm{ml}$ lipopolysaccharide (LPS) as described [42].

Bone marrow-derived MDSCs that resemble tumor MDSCs were generated as described [12]. Briefly, bone marrow cells were collected from femur and tibia, treated with red blood cell lyses buffer and washed with Dulbecco's Phosphate Buffered Saline (DPBS, SigmaAldrich, Zwijndrecht, Belgium). Bone marrow cells were cultured in $75 \%$ conditioned medium obtained from mouse GM-CSF secreting B16-F0 cells and 25\% Iscove's Modified Dulbecco's Medium (IMDM, Lonza, Verviers, Belgium). The culture was supplemented with 10\% fetal clone I (Harlan, Horst, the Netherlands), $100 \mathrm{U} / \mathrm{ml}$ penicillin, $100 \mu \mathrm{g} / \mathrm{ml}$ streptomycin and $2 \mathrm{mM}$ L-Glutamine (Sigma-Aldrich). The MDSC cultures were refreshed at day 3 and 5 and ready for use at day 5-7.

\section{In vitro OT-I stimulation assay}

In vitro generated DCs were pulsed with $5 \mu \mathrm{g} / \mathrm{ml}$ SIINFEKL (Eurogentec) for 90 minutes at $37^{\circ} \mathrm{C}$ in a humidified incubator. Subsequently, DCs were co-cultured at a 1:10 ratio with $\mathrm{CD}^{+} \mathrm{T}$ lymphocytes that were enriched from the spleen of OT-I mice using the CD8 $\mathrm{a}^{+} \mathrm{T}$ cell Isolation Kit II (Miltenyi Biotec, Gladbach, Germany). Supernatants of HEK293T cells that were electroporated with mRNA encoding eGFP or $F \beta^{2}$ were added to the co-cultures. On day 6, supernatants were collected and analyzed via ELISA for IFN- $\gamma$ production (eBioScience, San Diego, California, USA). GolgiPlug-containing medium was added and intracytoplasmatic staining for IFN- $\gamma$ was performed 24 hours later.

\section{$\mathrm{CD8}^{+} \mathrm{T}$ lymphocyte suppression assay}

$\mathrm{CD}^{+} \mathrm{T}$ lymphocytes were isolated from the spleen of $\mathrm{C} 57 \mathrm{BL} / 6$ mice using the $\mathrm{CD} 8 \alpha^{+} \mathrm{T}$ cell Isolation Kit II and were co-cultured with in vitro generated MDSCs at the indicated ratios in the presence of anti-CD3/antiCD28 antibody coated microbeads (Invitrogen, Oslo, Norway) and $100 \mathrm{U} / \mathrm{ml}$ IL-2 (Peprotech, Rocky Hill, New Jersey, USA). Non-stimulated $\mathrm{CD}^{+} \mathrm{T}$ lymphocytes and $\mathrm{CD}^{+} \mathrm{T}$ lymphocytes stimulated in the absence of MDSCs were used as a control. Three days after the 
start of the co-culture the supernatants were collected and the production of IFN- $\gamma$ was analyzed by ELISA (eBioScience).

\section{CD107a assay}

Isolated $\mathrm{CD} 8^{+}$OT-I cells were stimulated with anti$\mathrm{CD} 3 /$ anti-CD28 coated microbeads and cultured in $\mathrm{F} \beta^{2}$ or control supernatants for three days. Simultaneously E.G7-OVA tumor cells were cultured in $\mathrm{F}^{2}$ or control supernatants and EL4 cells were used as a negative control. After three days, the cells were thoroughly washed, mixed and co-cultured in the presence of fluorescein isothiocyanate (FITC)-conjugated CD107a antibodies (Becton Dickinson [BD], Erembodegem, Belgium). Four hours later, the cells were washed and additionally stained for $\mathrm{CD} 3$ and $\mathrm{CD} 8$, after which all samples were acquired on the LSRFortessa (BD).

\section{Flow cytometry}

Staining of cell surface markers was previously described [43]. The following antibodies were used: FITC-conjugated antibodies against CD11b (BD), AlexaFluor647 (AF647)-conjugated antibodies against CD11c and Ly6G (BioLegend, San Diego, California, USA), PE-conjugated antibodies against CD4 (BD), CD11b, MHC II (BioLegend), CD25, PD-L1 and PD-1 (eBioScience), PE-Cy7-conjugated antibodies against Ly6C (BioLegend), PercP-Cy5.5-conjugated antibodies against CD3 (BioLegend) and CD4 (BD), Pacific Blueconjugated antibodies against CD3 (BioLegend), Brilliant Violet 605-conjugated antibodies against CD45 (BD), APC-conjugated antibodies against Foxp3 (eBioScience), APC-H7-conjugated antibodies against CD8 (BD), Brilliant Violet-conjugated antibodies against $\mathrm{CD} 3$ (BioLegend) and FITC-conjugated MHC class I (H2$\mathrm{K}^{\mathbf{b}}$, prepared in-house), PE-Cy7-conjugated antibodies against IFN- $\gamma$ (eBioScience). Data were collected using the FACSCanto or LSRFortessa Flow Cytometer (BD) and analysis was performed with FACSDiva (BD) or Flow Jo 7 software (Tree Star Inc., Ashland, Oregon, USA).

\section{Enzyme-linked Immunosorbent Assay}

Supernatants were screened in a sandwich ELISA for the presence of IL-6, IL-12, TNF- $\alpha$ or IFN- $\gamma$ (eBioscience).

\section{Colorimetric assay (MTS assay)}

To assess the viability of MDSCs and tumor cell proliferation, an MTS (3-(4,5-dimethylthiazol-2-yl)-5-(3carboxymethoxyphenyl)-2-(4-sulfophenyl)-2H-tetrazolium) assay was performed according to the manufacturer's protocol (Promega, Wisconsin, USA).

\section{Statistical analysis}

Comparison of two data sets was performed using the unpaired student's t-test. For the comparison of more than three groups, we performed a one-way ANOVA followed by a Bonferroni's multiple comparison test. Number of asterisks in the figures indicates the level of statistical significance as follows: ${ }^{*}, p<0.05 ;{ }^{* *}, p<$ $0.01 ; * * *, p<0.001$. The results are shown in a column graph or table as the mean \pm standard error of the mean (SEM). Survival was visualized in a Kaplan-Meier plot. Differences in survival were analyzed by the log-rank test.

\section{ACKNOWLEDGMENTS}

We thank Dr. Federico Sandoval for reviewing the manuscript and Petra Roman, Elsy Vaeremans, Xavier Debaere and Angelo Willems for their technical assistance.

\section{GRANT SUPPORT}

This work was supported by grants from the Interuniversity Attraction Poles Program-Belgian StateBelgian Science Policy, the National Cancer Plan of the Federal Ministry of Health, the Stichting tegen Kanker, the Vlaamse Liga tegen Kanker, an Integrated Project and an EU FP7-funded Network of Excellence, an IWT-TBM program, the FWO-Vlaanderen and the Scientific Fund Willy Gepts of the University Hospital Brussels. KVdJ and LB are supported by the IWT. KB is a postdoctoral fellow of the FWO-Vlaanderen. DE is funded by a Miguel Servet Fellowship from the Instituto de Salud Carlos III, Spain. TL received an overseas research scholarship, UCL, United Kingdom.

\section{Conflict of interest}

The authors declare that there is no conflict of interest.

\section{REFERENCES}

1. Frey AB. Signaling defects in anti-tumor T cells. 2008: 192-205.

2. Emeagi PU, Goyvaerts C, Maenhout S, Pen J, Thielemans K, Breckpot K. Lentiviral vectors: a versatile tool to fight cancer. Curr. Mol. Med. 2013; 13:602-25.

3. Marabelle a, Kohrt H, Caux C, Levy R. Intratumoral Immunization: A New Paradigm for Cancer Therapy. Clin. Cancer Res. 2014; 20:1747-1756.

4. Van Lint S, Renmans D, Benteyn D, Goyvaerts C, Maenhout S, Broos K, Du four S, Goethals L, Van der Jeught K, Bialkowski L, Heirman C, Thielemans K, Breckpot K. Intratumoral immunotherapy using mRNA 
encoding CD40 Ligand, active TLR4 and CD70. JNCI 2014. Under revision.

5. Van Lint S, Renmans D, Broos K, Dewitte H, Lentacker I, Heirman C, Breckpot K, Thielemans K. The ReNAissanCe of mRNA-based cancer therapy. Exp. Rev. Vaccines. Accepted 2014.

6. Van Lint S, Maenhout S, Benteyn D, Heirman C, Breckpot K, Thielemans K. Intratumoral and Intranodal Administration of Trimix and Antigen MRNA Results in Effective Anti-tumor Immunity. J. Immunother. 2012; 35: 745-745.

7. Penafuerte C, Bautista-Lopez N, Bouchentouf M, Birman E, Forner K, Galipeau J. Novel TGF-beta antagonist inhibits tumor growth and angiogenesis by inducing IL-2 receptordriven STAT1 activation. J. Immunol. 2011; 186: 6933-6944.

8. Penafuerte C, Galipeau J. FIST, a sword and shield fusokine for cancer immunotherapy. Oncoimmunology. 2012; $1: 224-226$.

9. Terabe M, Ambrosino E, Takaku S, O'Konek JJ, Venzon D, Lonning S, McPherson JM, Berzofsky JA. Synergistic enhancement of CD8+ T cell-mediated tumor vaccine efficacy by an anti-transforming growth factor-beta monoclonal antibody. Clin. Cancer Res. 2009; 15:6560-9.

10. Diamond MS, Kinder M, Matsushita H, Mashayekhi M, Dunn GP, Archambault JM, Lee H, Arthur CD, White JM, Kalinke U, Murphy KM, Schreiber RD. Type I interferon is selectively required by dendritic cells for immune rejection of tumors. J. Exp. Med. 2011; 208:1989-2003.

11. Arce F, Breckpot K, Stephenson H, et al. Selective ERK activation differentiates mouse and human tolerogenic dendritic cells, expands antigen-specific regulatory T cells, and suppresses experimental inflammatory arthritis. Arthritis Rheum. 2011; 63:84-95.

12. Liechtenstein T, Perez-Janices N, Blanco-Luquin I, Goyvaerts C, Schwarze J, Dufait I, Lanna A, De Ridder M, Guerrero-Setas D, Breckpot K, Escors D. Antimelanoma vaccines engineered to simultaneously modulate cytokine priming and silence PD-L1 characterized using ex vivo myeloid-derived suppressor cells as a readout of therapeutic efficacy. Oncoimmunology. 2014; 3:e29178.

13. Liechtenstein T, Perez-Janices N, Gato M, Caliendo F, Kochan G, Blanco-Luquin I, Van der Jeught K, Arce F, Guerrero-Setas, Fernandez-Irigoyen J, Santamaria E, Breckpot K, Escors D. A highly efficient tumorinfiltrating MDSC differentiation system for discovery of anti-neoplastic targets, which circumvents the need for tumor establishment in mice. Oncotarget; Adv. Online Publ. 2014.

14. Lizée G, Overwijk WW, Radvanyi L, Gao J, Sharma P, Hwu P. Harnessing the power of the immune system to target cancer. Annu. Rev. Med. 2013; 64:71-90.
15. Benteyn D, Van Nuffel AMT, Wilgenhof S, Corthals J, Heirman C, Neyns B, Thielemans K, Bonehill A. Characterization of $\mathrm{CD} 8+\mathrm{T}$-cell responses in the peripheral blood and skin injection sites of melanoma patients treated with mRNA electroporated autologous dendritic cells (TriMixDC-MEL). Biomed Res. Int. 2013; 2013:976383.

16. Topalian SL, Hodi FS, Brahmer JR, Gettinger SN, Smith DC, McDermott DF, Powderly JD, Carvajal RD, Sosman JA, Atkins MB, Leming PD, Spigel DR, Antonia SJ, et al. Safety, Activity, and Immune Correlates of AntiPD-1 Antibody in Cancer. N. Engl. J. Med. 2012; 366: 2443-2454.

17. Brahmer JR, Tykodi SS, Chow LQM, Hwu WJ, Topalian SL, Hwu P, Drake CG, Camacho LH, Kauh J, Odunsi K, Pitot HC, Hamid O, Bhatia S, et al. Safety and Activity of Anti-PD-L1 Antibody in Patients with Advanced Cancer. N. Engl. J. Med. 2012; 366:2455-2465.

18. Hodi FS, O'Day SJ, McDermott DF, Weber RW, Sosman JA, Haanen JB, Gonzalez R, Robert C, Schadendorf D, Hassel JC, Akerley W, van den EertWegh AJM, Lutzky J, et al. Improved survival with ipilimumab in patients with metastatic melanoma. N. Engl. J. Med. 2010; 363:711-723.

19. Kim S, Buchlis G, Fridlender ZG, Sun J, Kapoor V, Cheng G, Haas A, Cheung HK, Zhang X, Corbley M, Kaiser LR, Ling L, Albelda SM. Systemic blockade of transforming growth factor-beta signaling augments the efficacy of immunogene therapy. Cancer Res. 2008; 68:10247-10256.

20. Breckpot K, Corthals J, Bonehill A, Michiels A, Tuyaerts S, Aerts C, Heirman C, Thielemans K. Dendritic cells differentiated in the presence of IFN-beta and IL-3 are potent inducers of an antigen-specific CD8 $+\mathrm{T}$ cell response. J. Leukoc. Biol. 2005; 78:898-908.

21. Santini SM, Lapenta C, Logozzi M, Parlato S, Spada M, Di Pucchio T, Belardelli F. Type I interferon as a powerful adjuvant for monocyte-derived dendritic cell development and activity in vitro and in Hu-PBL-SCID mice. J. Exp. Med. 2000; 191:1777-88.

22. Fuertes MB, Kacha AK, Kline J, Woo SR, Kranz DM, Murphy KM, Gajewski TF. Host type I IFN signals are required for antitumor $\mathrm{CD} 8+\mathrm{T}$ cell responses through CD8alphat dendritic cells. J. Exp. Med. 2011; 208: 2005-16.

23. Narumi K, Udagawa T, Kondoh A, Kobayashi A, Hara H, Ikarashi Y, Ohnami S, Takeshita F, Ochiya T, Okada T, Yamagishi M, Yoshida T, Aoki K. In vivo delivery of interferon- $\alpha$ gene enhances tumor immunity and suppresses immunotolerance in reconstituted lymphopenic hosts. Gene Ther. 2012; 19:34-48.

24. Maenhout SK, Van Lint S, Emeagi PU, Thielemans K, Aerts JL. Enhanced suppressive capacity of tumor-infiltrating myeloid-derived suppressor cells compared with their peripheral counterparts. Int. J. Cancer. 2014; 134:1077-90. 
25. Huang B, Pan PY, Li Q, Sato AI, Levy DE, Bromberg J, Divino CM, Chen SH. Gr-1+CD115+ immature myeloid suppressor cells mediate the development of tumor-induced $\mathrm{T}$ regulatory cells and T-cell anergy in tumor-bearing host. Cancer Res. 2006; 66:1123-31.

26. Umemura N, Saio M, Suwa T, Kitoh Y, Bai J, Nonaka K, Ouyang GF, Okada M, Balazs L, Adany R, Shibata T, Takami T. Tumor-infiltrating myeloid-derived suppressor cells are pleiotropic-inflamed monocytes/macrophages that bear M1- and M2-type characteristics. J. Leukoc. Biol. 2008; 83:1136-44.

27. Ostrand-Rosenberg S, Sinha P. Myeloid-derived suppressor cells: linking inflammation and cancer. J. Immunol. 2009; 182:4499-506.

28. Zoglmeier C, Bauer H, Nörenberg D, Wedekind G, Bittner P, Sandholzer N, Rapp M, Anz D, Endres S, Bourquin C. CpG blocks immunosuppression by myeloid-derived suppressor cells in tumor-bearing mice. Clin. Cancer Res. 2011; 17:1765-75.

29. Ellermeier J, Wei J, Duewell P, Hoves S, Stieg MR, Adunka T, Noerenberg D, Anders HJ, Mayr D, Poeck H, Hartmann G, Endres S, Schnurr M. Therapeutic efficacy of bifunctional siRNA combining TGF- $\beta 1$ silencing with RIG-I activation in pancreatic cancer. Cancer Res. 2013; 73:1709-20.

30. Hofbauer GF, Geertsen R, Laine E, Burg G, Dummer R. Impact of interferons on the expression of melanomaassociated antigens in melanoma short-term cell cultures. Melanoma Res. 2001; 11:213-8.

31. Mapara MY, Sykes M. Tolerance and cancer: mechanisms of tumor evasion and strategies for breaking tolerance. J. Clin. Oncol. 2004; 22:1136-51.

32. Pen JJ, Keersmaecker BD, Heirman C, Corthals J, Liechtenstein T, Escors D, Thielemans K, Breckpot K. Interference with PD-L1/PD-1 co-stimulation during antigen presentation enhances the multifunctionality of antigen-specific T cells. Gene Ther. 2014; 21:262-271.

33. Liechtenstein T, Dufait I, Bricogne C, Lanna A, Pen J, Breckpot K, Escors D. PD-L1 / PD-1 Co-Stimulation, a Brake for T cell Activation and a T cell Differentiation Signal. J. Clin. Cell. Immunol. 2013:1-14.

34. Dong H, Strome SE, Salomao DR, Tamura H, Hirano F, Flies DB, Roche PC, Lu J, Zhu G, Tamada K, Lennon V, Celis E, Chen L. Tumor-associated B7-H1 promotes T-cell apoptosis: a potential mechanism of immune evasion. Nat. Med. 2002; 8:793-800.

35. Shi F, Shi M, Zeng Z, Qi RZ, Liu ZW, Zhang JY, Yang YP, Tien P, Wang FS. PD-1 and PD-L1 upregulation promotes CD8(+) T-cell apoptosis and postoperative recurrence in hepatocellular carcinoma patients. Int. J. Cancer. 2011; 128:887-96.

36. Karwacz K, Bricogne C, MacDonald D, Arce F, Bennett CL, Collins M, Escors D. PD-L1 co-stimulation contributes to ligand-induced $\mathrm{T}$ cell receptor down-modulation on $\mathrm{CD} 8+$ T cells. EMBO Mol. Med. 2011; 3:581-92.

37. Yang X, Zhang X, Fu ML, Weichselbaum RR, Gajewski TF, Guo Y, Fu YX. Targeting the Tumor Microenvironment with Interferon- $\beta$ Bridges Innate and Adaptive Immune Responses. Cancer Cell. 2014; 25:37-48.

38. Bald T, Landsberg J, Lopez-Ramos D, Renn M, Glodde N, Jansen P, Gaffal E, Steitz J, Tolba R, Kalinke U, Limmer A, Jönsson G, Hölzel M, et al. Immune-cell poor melanomas benefit from PD-1 blockade after targeted type I IFN activation. Cancer Discov. 2014. doi:10.1158/2159-8290. CD-13-0458.

39. Van den Boorn JG, Hartmann G. Turning tumors into vaccines: co-opting the innate immune system. Immunity. 2013; 39:27-37.

40. Arce F, Breckpot K, Stephenson H, Karwacz K, Ehrenstein MR, Collins M, Escors D. Selective ERK Activation Differentiates Mouse and Human Tolerogenic Dendritic Cells, Expands Antigen-Specific Regulatory T Cells, and Suppresses Experimental Inflammatory Arthritis. Arthritis Rheum. 2011; 63:84-95.

41. Van Lint S, Goyvaerts C, Maenhout S, Goethals L, Disy A, Benteyn D, Pen J, Bonehill A, Heirman C, Breckpot K, Thielemans K. Preclinical Evaluation of TriMix and Antigen mRNA-Based Antitumor Therapy. Cancer Res. 2012; 72:1661-1671.

42. Van Meirvenne S, Straetman L, Heirman C, Dullaers M, De Greef C, Van Tendeloo V, Thielemans K. Efficient genetic modification of murine dendritic cells by electroporation with mRNA. Cancer Gene Ther. 2002; 9:787-97.

43. Breckpot K, Dullaers M, Bonehill A, van Meirvenne S, Heirman C, De Greef C, van der Bruggen P, Thielemans K. Lentivirally transduced dendritic cells as a tool for cancer immunotherapy. J. Gene Med. 2003; 5:654-667. 